\title{
Anatomical Relationship Between Opioid Peptides and Receptors in Rhesus Monkey Brain
}

\author{
MICHAEL E. LEWIS, HENRY KHACHATURIAN, HUDA AKIL \\ AND STANLEY J. WATSON \\ Mental Health Research Institute, University of Michigan, Ann Arbor, MI 48109
}

Received 14 December 1984

\begin{abstract}
LEWIS, M. E., H. KHACHATURIAN, H. AKIL AND S. J. WATSON. Anatomical relationship between opioid peptides and recepters in rhesus monkey brain. BRAIN RES BULL 13(6) 801-812, 1984,- - To determine whether opioid peptidereceptor pharmacological associations found in vitro (e.g., enkephalin- $\delta$, dynorphin- $\kappa$ ) predict anatomical relationships in situ. immunocytochemical and receptor autoradiographic studies were carried out on adjacent sections from the same brains of formaldehyde-perfused thesus monkeys. Apparent $\mu$ and $\kappa$ opioid receptors (labeled, respectively, by $\left[{ }^{3} \mathrm{H}\right]$ naloxone and $\left[{ }^{3} \mathrm{H}\right] \mathrm{bremazocine}$ under different incubation conditions), but not $\delta$ opioid receptors (labeled by $\left[{ }^{3} \mathrm{H}\right] \mathrm{D}-\mathrm{Ala}{ }^{2}$, DLeu ${ }^{5}$-enkephalin), survived the fixation procedure, and were found to be colocalized throughout the brain. We have observed complex associations between these binding sites and one, two, or all three opioid peptide systems (i.e., proopiomelanocortin, proenkephalin, and prodynorphin) in different brain regions. These multiple opioid peptide-receptor subtype associations are apparent, for example, in neural systems involved in the processing of pain stimuli, and may be important for mediating different types of analgesia. Since differential processing of proenkephalin and prodynorphin can give rise to opioids of varying receptor selectivities, the colocalization of opioid receptor subtypes may signify that such processing is a key regulatory event in determining which receptor subtype is activated and, thus, the physiological consequences of opioid neurotransmission.
\end{abstract}

Opioid receptor autoradiography $\left[{ }^{3} \mathrm{H}\right]$ naloxone $\quad\left[{ }^{3} \mathrm{H}\right]$ bremazocine Proopiomelanocortin Enkephalin Dynorphin Rhesus monkey brain

THE existence of three precursors for opioid peptides has been clearly established by molecular biological studies $[8$, $16,24,45,51-53,62,63]$. These precursors are: (1) proopiomelanocortin (POMC), which gives rise to $\beta$-endorphin and its $\mathrm{NH}_{2}$-terminally acetylated and/or COOH-terminally cleaved forms; (2) proenkephalin, which contains four copies of Met-enkephalin and single copies of Leu-enkephalin, Met-enkephalin- $\mathrm{Arg}^{6}-\mathrm{Phe}^{7}$, and Metenkephalin- $\mathrm{Arg}^{6}-\mathrm{Gly}^{7}-\mathrm{Leu}^{*}$, and gives rise to extended enkephalin peptides such as BAM-22P; and (3) prodynorphin, which gives rise to $\alpha-\beta$-neo endorphin, dynorphin $A$, and dynorphin $\mathrm{B}$, all of which contain the Leu-enkephalin sequence at the $\mathrm{NH}_{2}$ terminus. The peptides derived from these three precursors are contained within three distinct sets of neural systems, as determined by numerous immunocytochemical studies (see $[1,28,37,75]$ for reviews). Although the precursors are neuronally segregated, the enkephalin and dynorphin systems, in particular, exhibit substantial anatomical contiguities in many brain regions [17, $25,30,48,77]$. Given the anatomical complexity and biochemical relatedness of the multiple opioid systems, it seems worth considering how the "messages" of these systems are differentiated at the receptor level. Despite a wealth of pharmacological and biochemical evidence for the existence of multiple opioid receptors (see [64] for review), the relationship of these receptors to multiple opioid systems is poorly understood. Nevertheless, pharmacological studies of the endogenous ligands have provided some rationale for making anatomical predictions of ligand-receptor associations. While the pentapeptide enkephalins appear to bind preferentially to the $\delta$ opioid receptor subtype [44], prodynorphin-related peptides are usually reported to exhibit selectivity for the $\kappa$ receptor subtype $[7,9,57,81]$. In contrast, $\beta$-endorphin binds equally well to the $\mu$ and $\delta$ opioid receptor subtypes [44], but not to the $\kappa$ subtype [34,57].

To begin to explore whether in vitro ligand-receptor associations predicted anatomical relationships in situ, we found that it was possible to carry out opioid immunocytochemical and receptor autoradiographic studies on adjacent sections from formaldehyde-perfused rat brain [38]. This initial study revealed an association, in many brain areas, between Leu-enkephalin, a putative $\delta$ ligand, and [3]]naloxone binding sites, which appear to correspond to $\mu$ opioid receptors under the conditions used. Further studies pointed to a complex relationship between [ $\left.{ }^{3} \mathrm{H}\right]$ naloxone binding sites and all three opioid systems in rat brain [40], a finding also obtained in preliminary studies of rhesus monkey brain [39]. In the present report, we extend the study of rhesus monkey brain to describe the relationship between the multiple opioid peptide systems and apparent $\mu$ and $\kappa$ opioid receptors. 
LIST OF ABBREVIATIONS

\begin{tabular}{llll}
\hline ac & anterior commissure & ot & optic tract \\
aq & cerebral aqueduct & pc & posterior commissure \\
at & anterior thalamus & pn & pons \\
bst & bed n. of stria terminalis & ps & presubiculum \\
cau & caudate & put & putamen \\
cc & corpus callosum & pv & periventricular $n$ of thalamus \\
ci & internal capsule & pvn & paraventricular n. \\
cl & claustrum & $\mathrm{s}$ & subiculum \\
cp & cerebral peduncle & sc & superior colliculus \\
dg & dentate gyrus & sgc & substantia grisea centralis \\
ip & interpeduncular $n$. & sn & substantia nigra \\
ls & lateral septum & son & supraoptic nucleus \\
m & molecular layer & st & stria terminalis \\
ma & mammillary n. & $\mathrm{v}$ & ventricle \\
me & median eminence & vta & ventral tegmental area \\
oc & optic chiasm & VI & cortical layer VI \\
\hline
\end{tabular}

\section{METHOD}

Adult rhesus monkeys (Macaca mulatta) were anesthetized with sodium pentobarbital $(30 \mathrm{mg} / \mathrm{kg}$, IV), respirated through an endotrachial tube, and perfused through the aorta with 2 liters of saline followed by 16 liters of $0.1 \mathrm{M}$ phosphate-buffer $4 \%$ formaldehyde. Some animals were treated, under anesthesia, with colchicine (1-3 mg intracerebroventricularly) 48 hours prior to perfusion. Following perfusion, the head was severed from the trunk, placed in a stereotaxic apparatus, and the top of the calvarium was removed. Within the skull, the brain was cut into $1 \mathrm{~cm}$ thick slices in the frontal or parasagital planes using a Kopf stereotaxic device with blades attached. The brain slices were removed from the skull, postfixed in buffered $4 \%$ formaldehyde for $2-4$ hours at $4^{\circ} \mathrm{C}$, and then transferred into $15 \%$ sucrose in $0.02 \mathrm{M}$ phosphate-buffered saline (PBS) for overnight incubation at $4^{\circ} \mathrm{C}$. The tissues were then frozen by immersion into isopentane at $-50^{\circ} \mathrm{C}$ followed by encasement in pulverized dry ice, and stored in a freezer at $-80^{\circ} \mathrm{C}$. The frozen tissue blocks were sectioned at $20 \mu \mathrm{m}$ in a Bright cryostat, and the sections were thaw-mounted onto subbed slides and stored in a freezer at $-80^{\circ} \mathrm{C}$.

\section{Immunocytochemistry}

Sections to be processed for immunocytochemistry were air-dried at room temperature and incubated at $37^{\circ} \mathrm{C}$ with normal goat serum (NGS, from GIBCO) at a dilution of $1 / 30$ for 10 minutes, followed by primary rabbit antisera (diluted with PBS containing $0.3 \%$ Triton X-100) against ACTH (to label POMC neurons), Leu-enkephalin, or dynorphin B(113) for one hour at $37^{\circ} \mathrm{C}$ and overnight at $4^{\circ} \mathrm{C}$. Control sections were incubated with primary antiserum preabsorbed with 1-20 $\mu \mathrm{M}$ concentrations of peptide against which the antiserum was raised, as well as with other peptides with amino acid sequences in common with the original peptide. For these cross-blocking studies, the primary antisera were preabsorbed with Leu-enkephalin, BAM-22P, dynorphin $\mathrm{B}(1-13)$, dynorphin $\mathrm{A}(1-17), \beta$-endorphin and ACTH (see $[26,27,29-33]$ for antisera characteristics). The next day, the sections were washed in PBS ( $3 \times 10$ minutes) and incubated with NGS for 10 minutes at $37^{\circ} \mathrm{C}$ followed by goat antirabbit serum (Arnel) at $1 / 100$ dilution for 30 minutes at $37^{\circ} \mathrm{C}$ and overnight at $4^{\circ} \mathrm{C}$. On the third day, the sections were washed in PBS and incubated with NGS for 10 minutes at $37^{\circ} \mathrm{C}$, followed by anti-horseradish peroxidase (anti-HRP) serum at $1 / 200$ dilution for 40 minutes at $37^{\circ} \mathrm{C}$. The sections were again washed with PBS and incubated with PBS containing $4 \mu \mathrm{g} / \mathrm{ml}$ HRP enzyme (Sigma, Type VI) for 40 minutes at $37^{\circ} \mathrm{C}$. The peroxidase reaction was carried out by incubating the sections in PBS containing $0.03 \% \quad \mathrm{H}_{2} \mathrm{O}_{z}$ and $0.125 \mathrm{mg} / \mathrm{ml}$ diaminobenzidine (Sigma) for 15 minutes at room temperature with constant stirring. The reacted sections were washed in distilled water ( $3 \times 10$ minutes), briefly osmicated $\left(2 \% \mathrm{OsO}_{4}\right)$, washed, dehydrated through ascending concentrations of ethanol and exylenes, and coverslipped in Permount.

\section{Receptor Autoradiography}

Sections adjacent or near to those processed for immunocytochemistry were processed for opioid receptor autoradiography $[21,22,38-40,42]$. In rhesus monkey cerebral cortex, $\left[{ }^{3} \mathrm{H}\right]$ naloxone and $\left[{ }^{3} \mathrm{H}\right] \mathrm{D}-\mathrm{Ala}^{2}$, D-Leu ${ }^{5}$-enkephalin. under carefully selected assay conditions, bind to different populations of sites which appear to correspond, respectively, to $\mu$ and $\delta$ opioid receptor subtypes $[4,21,22]$. In addition, $\left[{ }^{3} \mathrm{H}\right]$ bremazocine, in the presence of unlabelled $\mu$ and $\delta$ ligands, appears to bind selectively to $\kappa$ opioid receptors [9]. To label apparent $\mu$ sites, slide-mounted sections were incubated in $0.05 \mathrm{M}$ Tris $\mathrm{HCl}(\mathrm{pH} 7.55)$ containing $1 \mathrm{nM}$ $\left[{ }^{3} \mathrm{H}\right]$ naloxone (New England Nuclear, $37.7 \mathrm{Ci} / \mathrm{mmol}$ ) and 100 $\mathrm{mM} \mathrm{NaCl}$ at $4^{\circ} \mathrm{C}$ for 60 minutes. To label apparent $\delta$ sites, adjacent or nearby slide-mounted sections were incubated in $0.05 \mathrm{M}$ Tris $\mathrm{HCl}$ (pH 7.4) containing $1 \mathrm{nM}\left[{ }^{3} \mathrm{H}\right] \mathrm{D}$ Ala $^{2}, \mathrm{D}-\mathrm{Leu}^{5}$-enkephalin (New England Nuclear, 39.5 $\mathrm{Ci} / \mathrm{mmol}), 30 \mathrm{mM} \mathrm{NaCl}, 3 \mathrm{mM} \mathrm{Mn}(\mathrm{OAc})_{2}, 2 \mu \mathrm{M}$ guanosine triphosphate, $0.2 \%$ bovine serum albumin, and $80 \mu \mathrm{g}$ bacitracin $/ \mathrm{ml}$ at $25^{\circ} \mathrm{C}$ for 30 minutes. To label apparent $\kappa$ sites. adjacent or nearby sections were incubated in $0.05 \mathrm{M}$ Tris $\mathrm{HCl}$ (pH 7.4) containing $2 \mathrm{nM}\left[{ }^{3} \mathrm{H}\right]$ bremazocine (New England Nuclear, $32.3 \mathrm{Ci} / \mathrm{mmol}), 100 \mathrm{nM}$ D-Ala ${ }^{2} \mathrm{MePhe}^{4}$. Gly-ols-enkephalin (DAGO), and $100 \mathrm{nM}$ D-Thr ${ }^{2}$-Leu ${ }^{3}$ enkephalin-Thr ${ }^{8}$ (DTLET) at $25^{\circ} \mathrm{C}$ for 60 minutes. Incubations were terminated by transferring the slides through dishes containing $200 \mathrm{ml}\left(\right.$ at $\left.4^{\circ}\right)$ of $0.1 \mathrm{M}$ phosphatebuffered saline $\left(\mathrm{pH} \mathrm{7.4)}\right.$ for the $\left[{ }^{3} \mathrm{H}\right]$ naloxone-incubated slides ( $6 \times 20$ second washes) or $0.05 \mathrm{M}$ Tris $\mathrm{HCl}$ buffer (pH 7.55) for the $\left[{ }^{3} \mathrm{H}\right] \mathrm{D}-\mathrm{Ala}^{2}, \mathrm{D}-\mathrm{Leu}^{5}$-enkephalin-incubated slides (6) 20 second washes) and $\left[{ }^{3} \mathrm{H}\right]$ bremazocine-incubated 


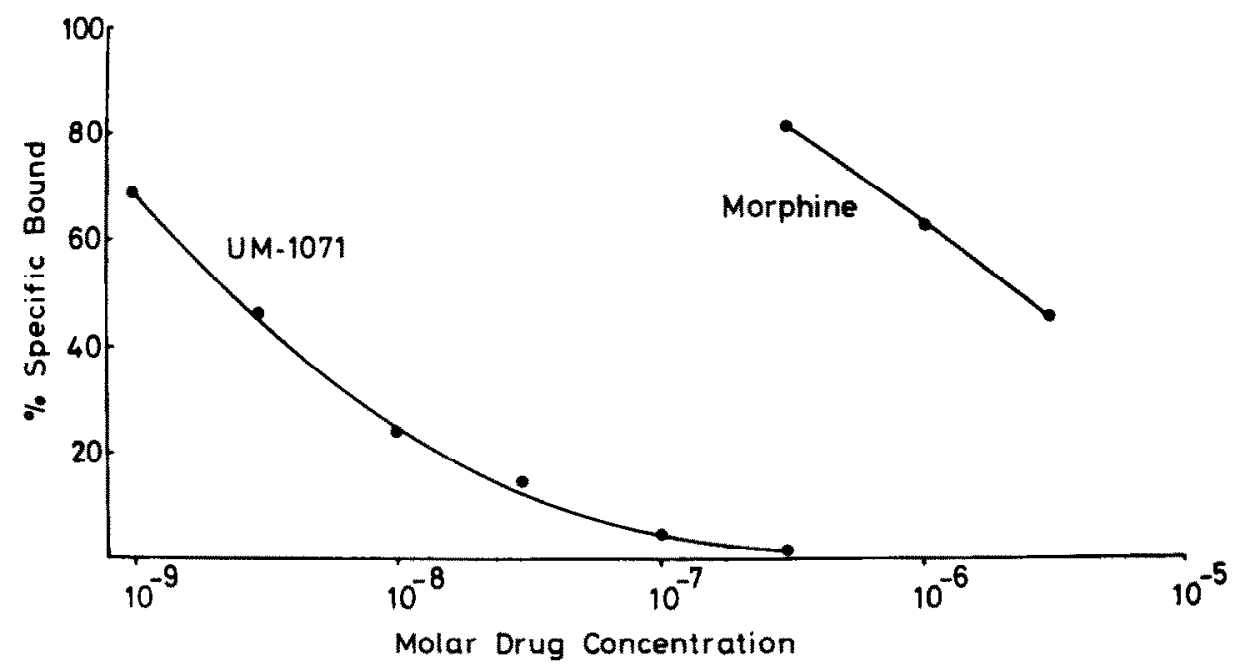

FIG. 1. Competition of UM-1071 (MR 2034) and morphine for specific $\left[{ }^{3} \mathrm{H}\right]$ bremazocine binding sites (in the presence of $100 \mathrm{nM}$ DAGO and DTLET) in brain sections from formaldehyde-perfused rhesus monkey (determinations in quadruplicate). Note the three order-of-magnitude difference in potency, indicating the $\kappa$ selectivity of the binding.

slides ( $4 \times 4$ minute washes). The slide-mounted sections were then dried under a stream of cold air.

Nonspecific binding was determined by adding 1-10 $\mu \mathrm{M}$ levorphanol (for $\mu$ and $\delta$ binding) or UM-1071 (for $\kappa$ binding) to the incubation media for some sections, and then measuring the bound radioactivity to elution into scintillation fluid (Safety-Solve; Research Products Int. Corp.) followed by liquid scintillation counting. Other sections prepared for nonspecific binding were saved for autoradiography.

The slide-mounted sections were processed for autoradiography using one of two methods. Some slides were arranged in $\mathrm{X}$-ray cassettes (Spectroline) and exposed to tritium-sensitive film ([3] Ultrofilm, LKB) for \&-16 weeks. The film was developed in $\mathrm{D}$-19 (Kodak) for 4 minutes at $19^{\circ} \mathrm{C}$, washed in $2 \%$ acetic acid for 30 seconds, fixed in Rapidfix (Kodak) for 5 minutes, rinsed in water for 20 minutes, dried, and then photographed using an enlarger. Other slides were exposed to paraformaldehyde vapors in vacuo at $80^{\circ} \mathrm{C}$ for 2 hours, demyelinated through ascending concentrations of ethanol, xylenes, and descending concentrations of ethanol, dried, and coated, under safelight illumination, with liquid emulsion (Kodak NTB2, diluted $1: 1$ with $0.1 \%$ Dreft detergent) [22]. The emulsion-coated sections were exposed in light-proof boxes for 8-16 weeks at $4^{\circ} \mathrm{C}$ and then developed in D-19 for 2 minutes at $16^{\circ} \mathrm{C}$, rinsed in water for 15 seconds, fixed in Rapidfix for 3 minutes, rinsed in water for 45 minutes, counterstained lightly with cresyl violet, and coverslipped in Permount. These sections were compared, using darkfield optics, to adjacent or nearby sections which had been processed for immunocytochemistry.

\section{RESULTS}

Scintillation counting studies demonstrated that $\left[{ }^{3} \mathrm{H}\right]$ naloxone binding to rhesus monkey brain sections was approximately $90 \%$ specific, which is comparable to results obtained in previous studies of both formaldehyde-fixed $[38,40]$ and unfixed $[42]$ rat brain sections. In contrast, virtually no specific binding of $\left[{ }^{3} \mathrm{H}\right] \mathrm{D}-\mathrm{Ala}^{2}, \mathrm{D}-\mathrm{Leu}^{5}$-enkephalin could be detected in the formaldehyde-fixed rhesus monkey brain sections. The efficacy of the labelling method was confirmed by demonstrating $85-90 \%$ specific binding of the tritiated peptide in unfixed rhesus monkey brain sections (data not shown). Binding of $\left[{ }^{3} \mathrm{H}\right]$ bremazocine to both fixed and unfixed rhesus monkey brain sections was $90-95 \%$ specific. To examine the $\kappa$ selectivity of this binding, competition studies were carried out with UM-1071 (MR 2034), a potent $\kappa$ agonist, and morphine, the prototypical $\mu$ agonist (Fig. 1). Under the conditions used, UM-1071 was three orders of magnitude more potent than morphine $\left(\mathrm{IC}_{50}=2.4 \mathrm{nM}\right.$ and $2.2 \mu \mathrm{M}$, respectively) in competition with $\left[{ }^{3} \mathrm{H}\right]$ bremazocine binding to fixed rhesus monkey brain sections,

The LKB Ultrofilm and Kodak wet emulsion autoradiographic methods gave the same results for $\left[{ }^{3} \mathrm{H}\right]$ naloxone localization, as reported before for rat brain $[22,42]$. However, bound $\left[{ }^{3} \mathrm{H}\right]$ bremazocine was not successfully vapor-fixed (see [35]), and was therefore localized using only Ultrofilm.

The anatomical loci of $\left[{ }^{3} \mathrm{H}\right]$ naloxone and $\left[{ }^{3} \mathrm{H}\right]$ bremazocine binding sites, using the incubation conditions described, were indistinguishable at every level of the central nervous system which was examined (e.g., Fig. 2). Thus, in the following anatomical descriptions, these sites are referred to as opioid binding sites.

The anatomical distribution of opioid binding sites is particularly pronounced in brain regions which also contain substantial amounts of opioid immunoreactive structures $[17,25,26]$. As an exception, however, the cerebral cortex and hippocampus/dentate gyrus contain a readily visualized population of opioid binding sites (Fig. 6), but very little or no apparent opioid immunoreactive perikarya or fibers. In the striatal complex, distinct patches of $\left[{ }^{3} \mathrm{H}\right]$ opioid binding sites are seen scattered throughout the caudate (Fig. 2). Both enkephalin and dynorphin immunoreactivity also exist in neuronal perikarya as well as fibers in caudate. Furthermore, POMC-immunoreactive fibers are seen in the rostral-ventral aspect of the head of caudate and putamen. The exact anatomical relationship of these opioid systems to opioid 
receptors is not clear at preseennt, and as is the case in the rat brain [40], no apparent correspondence is noted between receptor localization and peptide distribution. Enkephalin and dynorphin perikarya in caudate may project to the globus pallidus and the substantia nigra in monkey as they do in rat [71], but only modest levels of $\left[{ }^{3} \mathrm{H}\right]$ opioid binding sites are present in either of the latter two regions. Elsewhere in the telencephalon, the bed nucleus of stria terminalis contains a dense concentration of POMC fibers, enkephalin perikarya and terminals, and $\left[{ }^{3} \mathrm{H}\right.$ ]opioid binding sites (Fig. 3). Furthermore, in amygdala, the central and medial nuclei receive POMC projections, and contain enkephalin and dynorphin perikarya and fibers. Dense $\left[{ }^{3} \mathrm{H}\right.$ ]opioid binding is also seen in all regions of the amygdala.

In the preoptic area, the location of $\left[{ }^{3} \mathrm{H}\right]$ opioid binding sites (Figs. 3 and 4) corresponds to the distribution of a distinct bundle of immunoreactive POMC fibers coursing through this region. Numerous enkephalin and dynorphin neuronal perikarya and terminals also are seen scattered in the medial preoptic area.

Within the diencephalon, a particularly good correspondence can be seen between opioid peptides and binding sites (Figs. 4 and 5). Unlike in the rat brain, the rhesus monkey hypothalamus is very rich in $\left[{ }^{3} \mathrm{H}\right]$ naloxone and $\left[{ }^{3} \mathrm{H}\right]$ bremazocine binding sites. For example, exceptionally heavy labelling is seen in the external layer of the median eminence. Here also, a particularly rich network of enkephalin and POMC terminals is seen surrounding the portal capillaries (Fig. 5). Opioid binding is also heavy in the magnocellular paraventricular (Fig. 4) and supraoptic (Fig. 2) nuclei, as well as periventricular and infundibaular nuclei (Fig. 4). The magnocellular nuclei contain high quantities of dynorphin (Fig. 2) synthesized by the same neurons that also produce vasopressin [74]. These cells may also contain Leu-enkephalin; however, the biosynthetic source of this peptide in the magnocellular neurons is not clear at present. The paraventricular, and to a lesser extent, the supraoptic nucleus, are both innervated by POMC fibers. The infundibular nucleus is very rich in both POMC perikarya and fibers (Fig. 4). This region also contains scattered enkephalin and dynorphin neurons some of which may contribute fibers to the median eminence. In contrast, the lateral and posterior hypothalamic areas contain both lower levels of opioid peptides and $\left[{ }^{3} \mathrm{H}\right]$ opioid binding sites. In the thalamus, many nuclei are rich in $\left[{ }^{3} \mathrm{H}\right]$ opioid binding sites, and most of these nuclei also contain enkephalin immunoreactivity. The correspondence is particularly striking in the midline periventricular nucleus, which exhibits a dense accumulation of both binding sites as well as POMC and enkephalin fibers (Fig. 5).

In the region of midbrain, the interpeduncular nuclear complex contains a very dense population of $\left[{ }^{3} \mathrm{H}\right]$ opioid binding sites (Fig. 3). This nucleus also contains scattered enkephalin immunoreactive perikarya and fibers, yet is virtually devoid of any POMC immunoreactivity. Dorsally in midbrain, there is a clear correspondence in the relative densities of opioid binding sites and opioid immunoreactivity in the substantia grisea centralis (or periaqueductal gray). Here also, a distinct projection of POMC fibers is seen surrounding the cerebral aqueduct (Fig. 3)

In the brainstem, the parabrachial nucleus is richly innervated by POMC and enkephalin fibers and terminals and contains a high density of opioid binding sites. Other pontine nuclei and regions are apparently devoid of opioid peptides and binding sites. In the medulla, a good correspondence between all three opioid peptides and opioid binding sites is seen only in the nucleus tractuas solitarius and the spinal trigeminal nucleus. The latter nucleus, which is in effect the rostral extension of the spinal cord dorsal gray, is particularly rich in enkephalin immunoreactivity distributed in both perikarya and terminals, as well as $\left[{ }^{3} \mathrm{H}\right]$ opioid binding sites.

\section{DISCUSSION}

The present study has described anatomical relationships between multiple opioid immunoreactive systems and $\left[{ }^{3} \mathrm{H}\right]$ naloxone and $\left[{ }^{3} \mathrm{H}\right]$ bremazocine binding sites in adjacent or nearby sections from formaldehyde-perfused rhesus monkey brain. The preservation of $\left[{ }^{3} \mathrm{H}\right]$ naloxone binding sites following formaldehyde perfusion was also found for rat brain $[38,40]$, and we report here that $\left[{ }^{3} \mathrm{H}\right]$ bremazocine binding sites are also maintained after fixation. These $\left[{ }^{3} \mathrm{H}\right]$ bremazocine binding sites, labelled in the presence of $100 \mathrm{nM}$ concentrations of DAGO, a selective $\mu$ agonist [34], and DTLET, a selective $\delta$ agonist [82] appear to correspond to $\kappa$ opioid receptors. Bremazocine is a very potent $\kappa$ ligand [65] which should be $\kappa$-selective in the presence of excess concentrations of $\mu$ and $\delta$ ligands [9], as confirmed here in the competition experiment with UM-1071 (MR 2034) and morphine. The anatomical loci of $\left[{ }^{3} \mathrm{H}\right]$ bremazocine binding sites corresponded exactly with the distribution of $\left[{ }^{3} \mathrm{H}\right]$ naloxone binding sites. Although the $\left[{ }^{3} \mathrm{H}\right]$ naloxone incubations were carried out in the absence of $\delta$ and $\kappa$ ligands. there is substantial evidence that low concentrations of $\left[{ }^{3} \mathrm{H}\right]$ naloxone, under the incubation conditions used, selectively label $\mu$ opioid binding sites $([14,21,22,56]$ but see [43]). Even if $\left[{ }^{3} \mathrm{H}\right]$ naloxone labelled $\kappa$ as well as $\mu$ opioid receptors in rhesus monkey brain, the identical distribution of $\left[{ }^{3} \mathrm{H}\right]$ naloxone and $\left[{ }^{3} \mathrm{H}\right]$ bremazocine binding sites would still indicate the colocalization of $\mu$ and $\kappa$ receptors. Otherwise, the " $\mu$ component" of $\left[{ }^{3} \mathrm{H}\right]$ naloxone binding sites would not correspond to the distribution of $\left[{ }^{3} \mathrm{H}\right]$ bremazocine binding sites. and some anatomical discrepancy would he apparent. Colocalization of $\mu$ and $\kappa$ opioid binding sites has also been reported in rat brain $\mid 56]$. but not in guinea pig [ $14 \mid$ or human [46] brain. The extent to which these findings reflect authentic species differences $[10,58]$ or simply variation in the ways subtypes are labeled remains to be determined However, in primates, a clear species difference does appear to be present: $\left[{ }^{3} \mathrm{H}\right]$ bremazocine, in the presence of $\mu$ and $\delta$ ligands, binds heavily to interpeduncular nucleus in rhesus monkey brain (see Results), but not at all to this structure in human brain $[46]$.

The apparent colocalization of $\mu$ and $\kappa$ opioid receptors throughout rhesus monkey brain is in contrast to the differential distribution of apparent $\mu$ and $\delta$ opioid receptors in monkey cerebral cortex [41]. A similar pattern also holds for rat brain $[15,42,59]$. We were unable to examine the distribution of $\delta$ opioid receptors in the present study since virtually all $\left[{ }^{3} \mathrm{H}\right] \mathrm{D}-\mathrm{Ala}^{2}$, D-Leu ${ }^{5}$-enkephalin binding was abolished by formaldehyde perfusion. This fixation-induced loss of $\delta$ binding was also observed for rat brain [40], and may be indicative of a chemical difference in the opioid receptor subtypes [23] or possibly a shift in receptor conformation $[4,5]$, possibilities which we cannot presently discriminate.

The distribution of $\left[{ }^{3} \mathrm{H}\right]$ naloxone and $\left[{ }^{3} \mathrm{H}\right]$ bremazocine binding sites in formaldehyde-perfused rhesus monkey brain corresponds very closely to the localization previously reported in studies of unfixed brain with $\left[{ }^{3} \mathrm{H}\right]$ naloxone $[79]$ and 


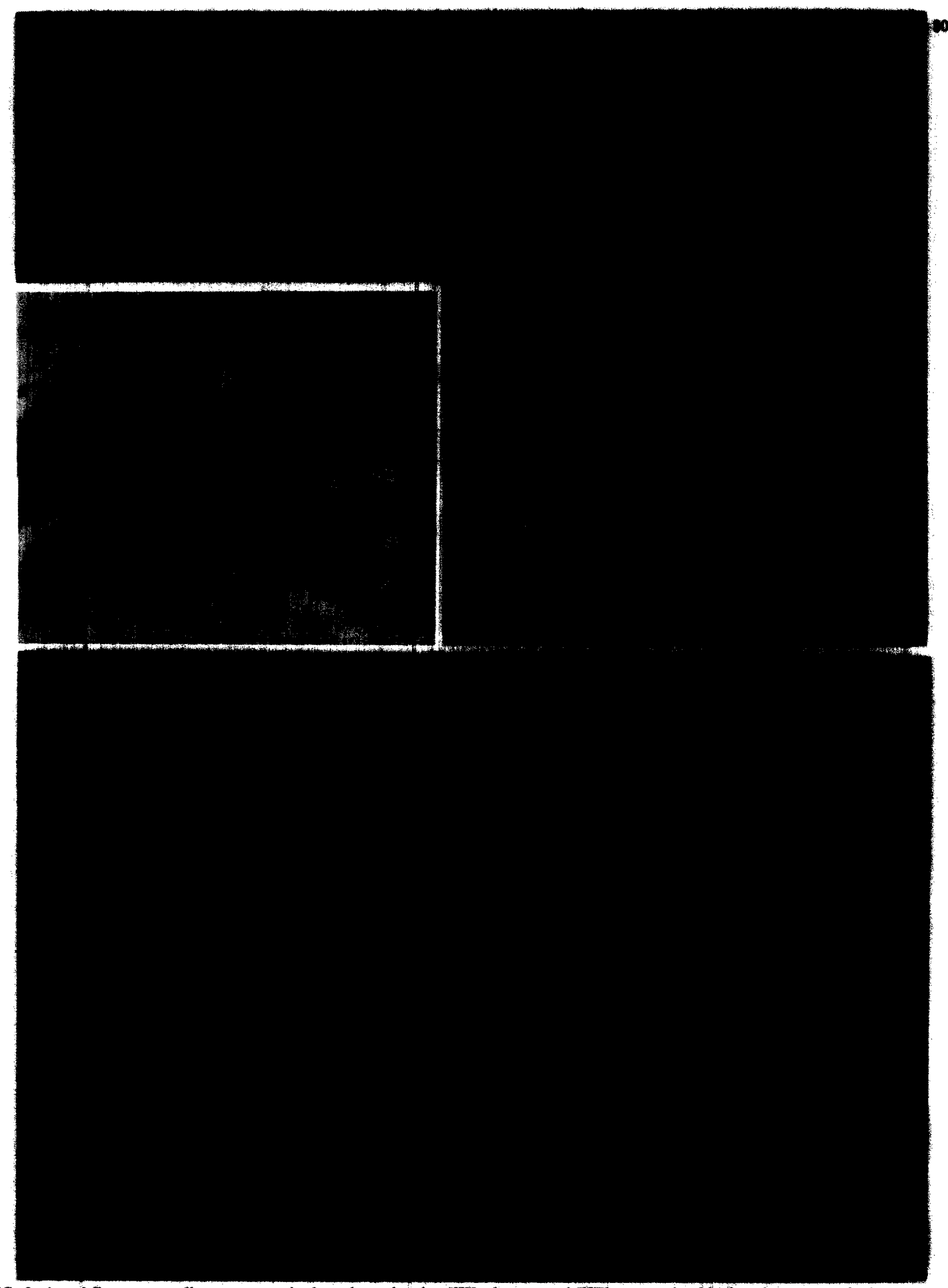

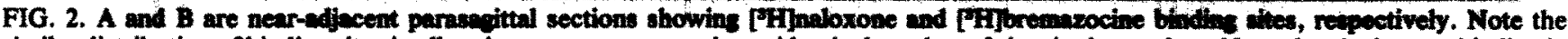
similar distribution of binding sites in all regions; e.g., arrows point to identical patches of sites in the caudate. Note also the intense binding in the supraoptic nucleus, and its correspondence with dynorphin $B(1-13)$ immunoreactive neurons in this nucleus (A: inset). 


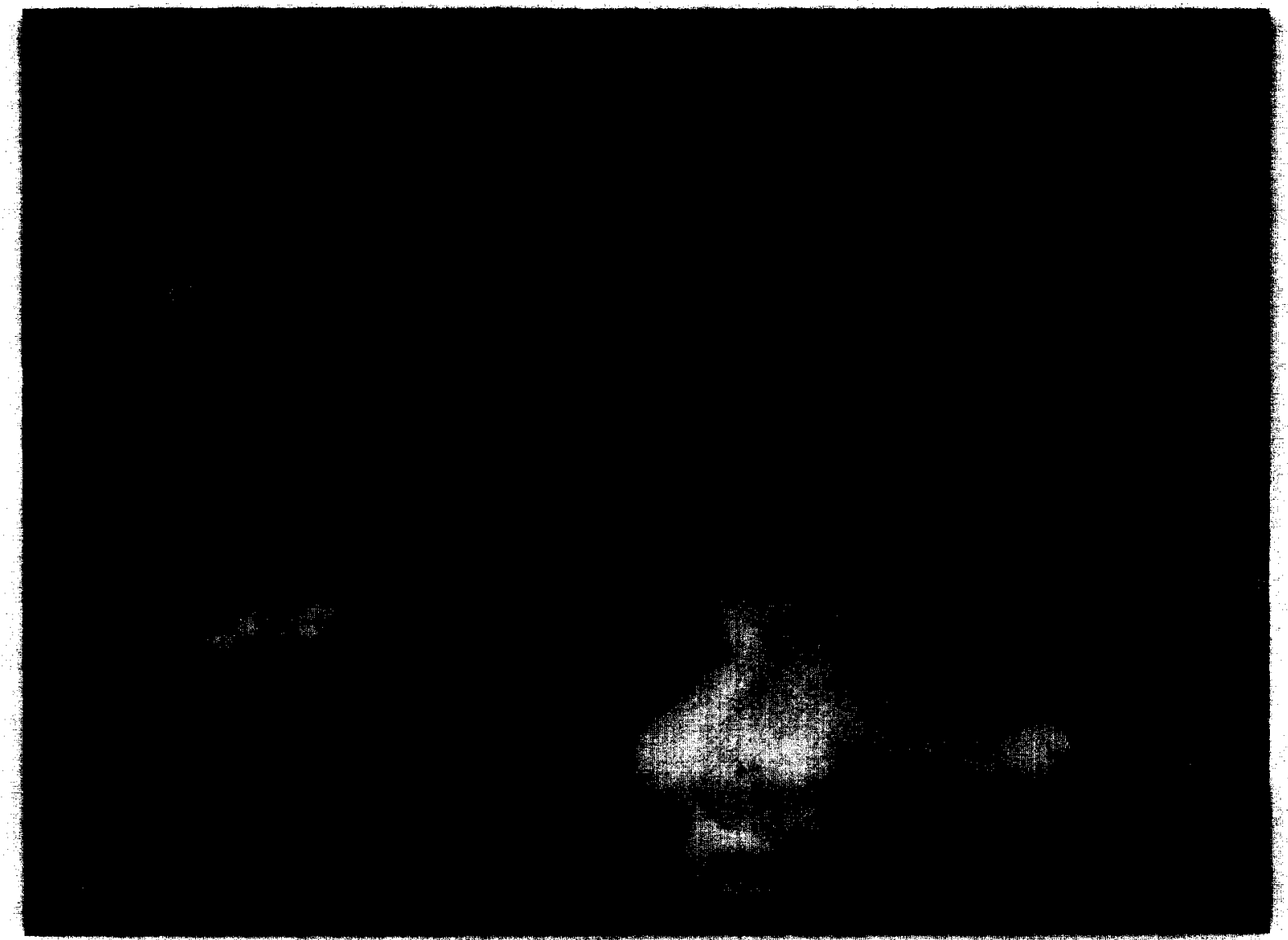

(3)

FIG. 3. A shows $\left[{ }^{3} \mathrm{H}\right]$ bremazocine binding sites in a parasagittal section. In adjacent sections $B$ and $C$ (see arrows in $A$ ), immunoreactive ACTH fibers are shown in the substantia grisea centralis (B) and the bed nucleus of stria terminalis (C). 

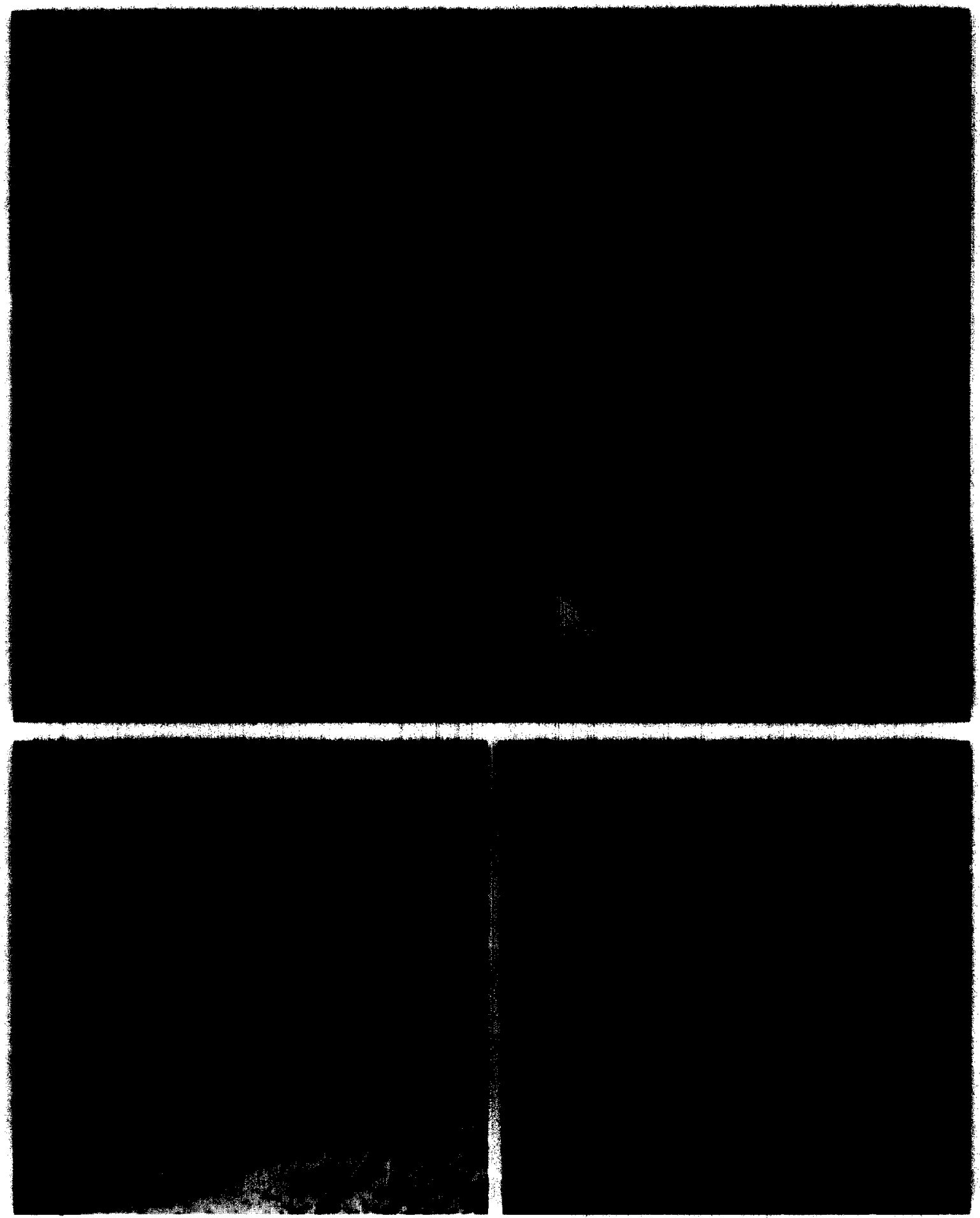

FIG. 4. In A, ['H]bremazocine binding sites are seen in a parasagittal section close to midline. B and C (see arrows in A) are adjacent sections which show the distribution of ACTH immunoreactive fibers in the infundibular nucleus (B) and the bed nucleus of anterior commissure (C). 

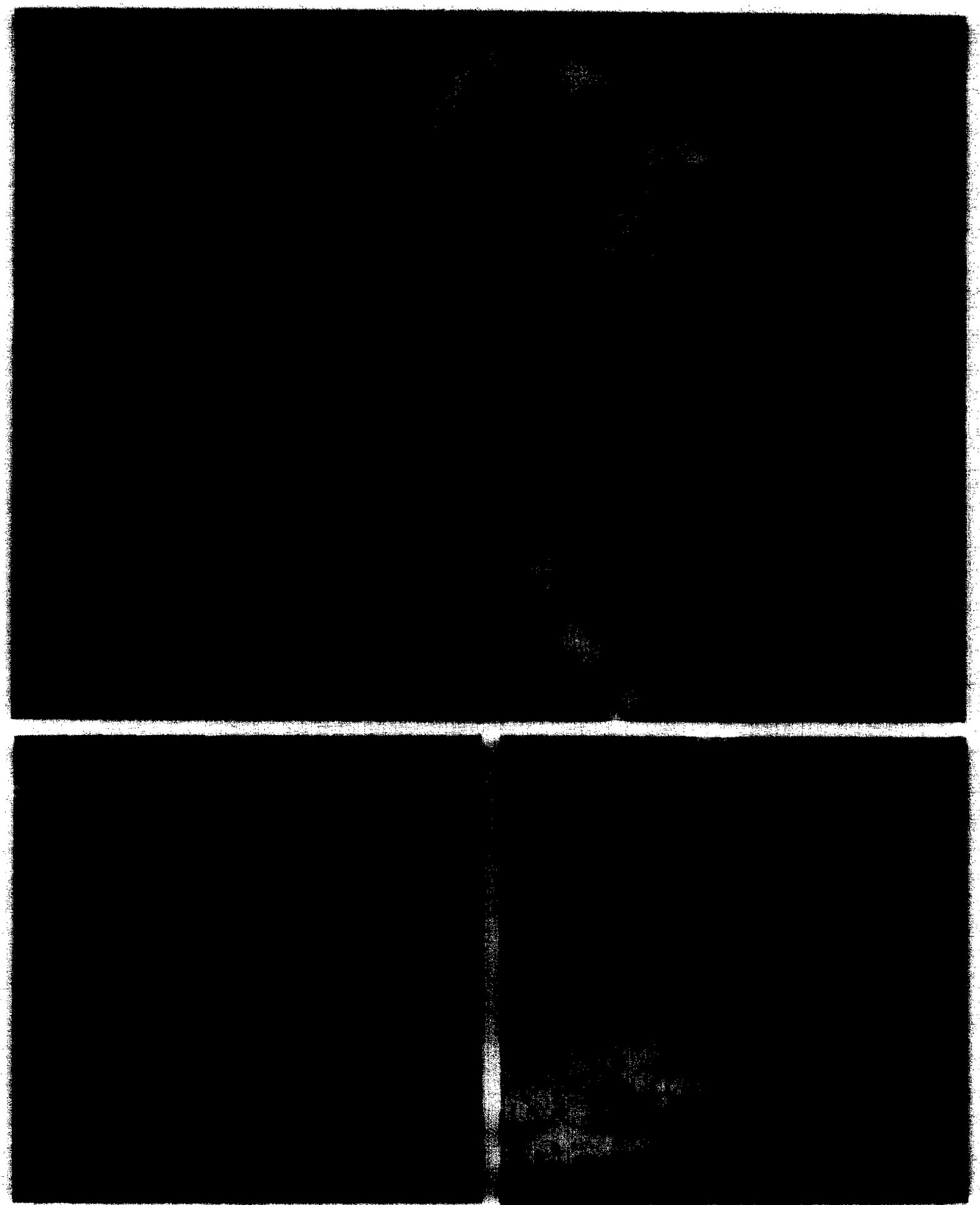

FIG. 5. [ $\left.{ }^{3} \mathrm{H}\right]$ bremazocine binding sites are seen in a mid-sagittal plane $(A)$. In adjacent sections $B$ and $C$ (see arrows in $A$ ), ACTH immunoreactive fibers are seen in the periventricular nucleus of thalamus (B), and diffuse Leu-enkephalin immunoreactivity is shown in the median eminence $(\mathrm{C})$. 


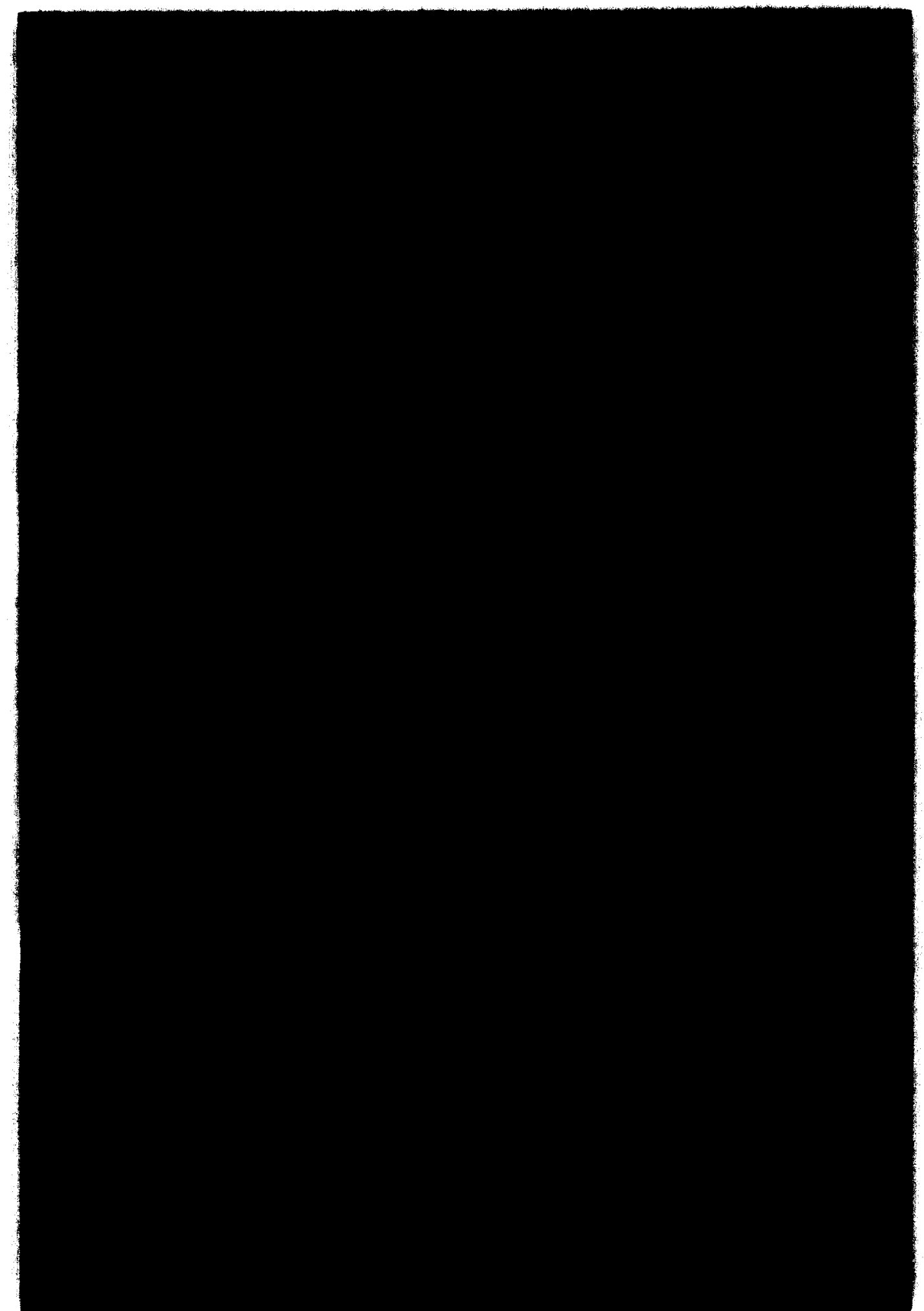

FIG. 6. In this fromtal section through the brain, Pfpbremazocine binding sites are seen concentrated in cortical layer VI (arrow points to area TE, visual association cortex), claustrum, presubiculum and subiculum, as well as stratum granulosum (g) and stratum moleculare (m) of the dentate gyrus. 
[ $\left.{ }^{3} \mathrm{H}\right]$ dipremorphine [73]. The preservation of the anatomical distribution of $\left[{ }^{3} \mathrm{H}\right]$ naloxone and $\left[{ }^{3} \mathrm{H}\right]$ bremazocine binding sites following formaldehyde perfusion has allowed us to perform receptor autoradiographic and opioid peptide immunocytochemical studies on adjacent sections from the same brain. Although general anatomical relationships between endogenous ligands and receptors can be discerned by comparing tissue sections from brains processed differentially for immunocytochemistry and autoradiography $[69,70]$. such comparisons are difficult due to problems in section alignment, the complexity of receptor distribution, and the anatomical relatedness of the multiple opioid systems in many regions.

Using adjacent section analysis, we have detected associations between apparent multiple opioid receptors and one, two, or all three opioid systems in many regions of rhesus monkey brain [39]. The neural systems involved in the processing of painful stimuli $[1,3,36]$ provide a good example of these multiple associations. The spinal trigeminal nucleus, the rostral continuation of the spinal cord dorsal gray, is particularly rich in both enkephalin and dynorphin perikarya and terminals and apparent $\mu$ and $\kappa$ opioid receptors. These peptide systems and receptors appear thoroughly interdigitated, at least at the light microscopic level. The periaqueductal gray, or substantia grisea centralis, contains substantial enkephalin and POMC (and some dynorphin) immunoreactivity which occurs in complex relation to the multiple opioid receptors. Stimulation of this region produces profound analgesia in monkeys $[47,54]$ and humans $[60,61]$, and the role of the multiple opioid systems and receptors in mediating antinociception requires further study. Thalamic nuclei involved in pain processing (e.g.. midline periventricular nucleus) also show a correspondence between POMC and enkephalin immunoreactivity and apparent $\mu$ and $\kappa$ opioid receptors. While much attention has been focused on the role of $\mu$ receptors in mediating opioid analgesia, $\kappa$ agonists also have significant antinociceptive actions, though apparently on different types of pain $[6,19$, $55,67,68$ ]. It is also worth noting that $\mu$ and $\kappa$ ligands produce centrally discriminable effects in rhesus monkeys $[20,80]$. Given the apparent colocalization of $\mu$ and $\kappa$ opioid receptors in the species used in the antinociception tests (rats) and drug discrimination paradigms (rhesus monkeys), the behavioral differentiation of $\mu$ and $\kappa$ effects has interesting implications. These opioid receptor subtypes, although colocalized at the light microscopic level, may have different synaptic loci (e.g., pre- vs. post- vs. non-synaptic) which would determine their actions. This question can perhaps be explored to some extent by electron microscopic localization of opioid receptors [18]. Still another possibility for $\mu-\kappa$ differentiation is at the level of receptor-effector relationships [4. 50, 78].
Despite the close correspondence of opioid peptides and receptors in many areas, there is no apparent relationship in other regions (see also $[37,40]$ ). For example, in cerebral cortex and hippocampus/dentate gyrus, no immunoreactivity could be detected (see also [17]), despite clear lamination of opioid binding sites in these areas. This discrepancy may be due to a relative lack of sensitivity of immunocytochemistry, since rhesus monkey cerebral cortex appears to contain measurable levels of met-enkephalin-like immunoreactivity as determined by radioimmunoassay (unpublished results). In rat, also, autoradiographic procedures had demonstrated cortical opioid receptors [2] at a time when inmunocytochemical studies failed to detect significant cortical opioid peptide immunoreactivity $[11,69,76]$. However. as a result of technical improvements, later immunocytochemical studies did show enkephalin and dynorphin perikarya and fibers in rat cerebral cortex $[12,13,27$. $28,32,33,48,49,66,72]$.

The purpose of the studies described here was to determine whether the anatomical relationship of opioid peptide systems and receptors was related to peptide-receptor affinities in vitro. The complexity of the association between the multiple opioid systems and apparent $\mu$ and $\kappa$ opioid receptors evidently precludes a straightforward one-to-one view of opioid peptide-receptor relationships. Thus. the anatomical associations predicted by in iviro receptor studies (e.g., enkephalin- $\delta$ or dynorphin- $\kappa$ ) are too simplistic. Indeed, the prediction itself was too simplistic, since it is now known that the dynorphin and enkephalin precursors can give rise to a diversity of opioids with widely differing receptor selectivities. For example, some extended proenkephalin peptides have $\mu$ and $\kappa$ activity [57], while the $\kappa$ selectivity of dynorphin $A$ is lost upon $\mathrm{COOH}$-terminal cleavage $[9,57]$. Since differential processing of proenkephalin and prodynorphin can give rise to opioids of varying receptor selectivities, the colocalization of opioid receptor subtypes may signify that such processing is a key regulatory event in determining which receptor subtype is activated and, thus, the physiological consequences of opioid neurotransmission.

\section{ACKNOWLEDGEMENT}

We wish to thank Adele Henry for manuscript preparation, and Sharon Burke and Giulio Baldrighi for technical assistance. This work was supported by NIMH Grant MH36168, NIDA Grant DA02265, NIDA Center Grant DA00154, NIMH Training Grant MH15794 (M.E.L.) and the Theophile Raphael Fund.

\section{REFERENCES}

1. Akil, H., S. J. Watson, E. Young, M. E. Lewis, H. Khachaturian and J. M. Walker. Endogenous opioids: Biology and function. In: Annual Review of Neuroscience, vol 7, edited by W. M. Cowan. Palo Alto: Annual Reviews Inc., 1984, pp. 223-255.

2. Atweh, S. and M. J. Kuhar. Autoradiographic localization of opiate receptors in rat brain. III. The telecephalon. Brain Re's 134: $393-405,1977$

3. Basbaum, A. I. and H. L. Fields. Endogenous pain control systems: Brainstem spinal pathways and endorphin circuitry. Annu Rev Neurosci 7: 309-338. 1984
4. Bowen, W. D., S. Gentleman, M. Herkenham and C. B. Pert. Interconverting mu and delta forms of the opiate receptor in rat striatal patches. Proc Nall Acad Sci USA 78: 4818-4822, 1981.

5. Bowen, W. D. and C. B. Pert. Conformational malleability of opiate receptors: Sulfhydryl modification alters ion-induced $\mathrm{mu} /$ delta-ligand selectivity shifts in rat striatal sections. Cell $\mathrm{Mol}$ Neurobiol 2: 115-128, 1982.

6. Calthrop, J. and R. G. Hill. The action of K-agonists on the nociceptive responses of neurones in the medullary dorsal horn of the anaesthetized rat. Life S S $i$ 33: Suppl 1, 541-544. 1983. 
7. Chavkin, C., I. James and A. Goldstein. Dynorphin is a specific endogenous ligand of the kappe opioid receptor. Science 215: 413-415, 1932.

8. Comb, M., P. Seeburg, J. Adelman, L. Eiden and E. Herbert. Primary structure of the human Met- and Leu-enkephalin precursor and its mRNA. Nature 295: 663-666, 1982.

9. Corbett, A. D., S. J. Paterson, A. T. McKnight, J. Magman and H. Kosterlitz. Dynorphin(1-8) and dynorphin(1-9) are ligands for the kappa subtype of opiate receptor. Nature 299: 79-81, 1982.

10. Edley, S. M., L. Hall, M. Herkenham and C. B. Pert. Evolution of striatal opiate receptors. Brain Res 269: 184-188, 1982.

11. Elde, R., T. Hokfelt, O. Johansson and L. Terenius. Immunohistochemical studies using antibodies to leucineenkephalin: Initial observations on the nervous system of the rat. Neuroscience 1: 349-351, 1976.

12. Finley, J. C. W., J. L. Maderdrut and P. Petrusz. The immunocytochemical localization of enkephalin in the central nervous system of the rat. J Comp Neurol 196: 541-565, 1981.

13. Gall, C., N. Brecha, H. J. Karten and K.-J. Chang. Localization of enkephalin-like immunoreactivity to identified axonal and neuronal populations of the rat hippocampus. J Comp Neurol 198: 335-350, 1981.

14. Goodman, R. R. and S. H. Snyder. Autoradiographic localization of kappa opiate receptors to deep layers of the cerebral cortex may explain unique sedative and analgesic effects. Life Sci 31: 1291-1294, 1982.

15. Goodman, R. R., S. H. Snyder, M. J. Kuhar and W. S. Young, III. Differentiation of delta and mu opiate receptor localizations by light microscopic autoradiography. Proc Natl Acad Sci USA 77: 6239-6243, 1980 .

16. Gubler, U., P. Seeburg, B. J. Hoffman, L. P. Gage and S. Udenfriend. Molecular cloning establishes proenkephalin as precursor of enkephalin-containing peptides. Nature 295: 206208, 1982.

17. Haber, S. and R. Elde. The distribution of enkephalin immunoreactive fibers and terminals in the monkey central nervous system: An immunohistochemical study. Neuroscience 7: 1049-1095, 1982.

18. Hamel, E. and A. Beaudet. Electron microscopic autoradiographic localization of opioid receptors in rat neostriatum. $\mathrm{Na}$ ture 312: 155-157, 1984.

19. Hayes, A. G., M. Skingle and M. B. Tyers. Antinociceptive profile of dynorphin in the rat. Life Sci 33: Suppl 1, 657-660, 1983.

20. Hein, D. W., A. M. Young, S. Herling and J. H. Woods. Pharmacological analysis of the discriminative stimulus characteristics of ethylketazocine in the rhesus monkey.J Pharmacol Exp Ther 218: 7-15, 1981.

21. Herkenham, M. and C. B. Pert. In vitro autoradiography of opiate receptors in rat brain suggests loci of "opiatergic" pathways. Proc Natl Acad Sci USA 77: 5532-5536, 1980.

22. Herkenham, M. and C. B. Pert. Light microscopic localization of brain opiate receptors: A general autoradiographic method which preserves tissue quality. $J$ Neurosci 2: 1129-1149, 1982.

23. Hiller, J. M., L. M. Angel and E. J. Simon. Multiple opiate receptors: Alcohol selectively inhibits binding to delta receptors. Science 214: 468-469, 1981.

24. Kakidani, H., Y. Furutani, H. Takehashi, M. Noda, Y. Morimoto, T. Hirose, M. Asai, S. Inayama, S. Nakanishi and S. Numa. Cloning and sequence analysis of cDNA for porcine beta-neo-endorphin/dynorphin precursor. Nature 298: 245-249, 1982.

25. Khachaturian, H., M. E. Lewis, M. D. Fitzsimmons and S. J. Watson. Immunocytochemical studies of dynorphin distribution in the rhesus monkey central nervous system. Soc Neurosci Abstr 10: 590, 1984.

26. Khachaturian, H., M. E. Lewis, S. Haber, H. Akil and S. J. Watson. Proopiomelanocortin peptide immunocytochemistry in the rhesus monkey brain. Brain Res Bull 13: 785-800, 1984.
27. Khachaturian, H., M. E. Lewis, V. Hollt and S. J. Watson. Telencephalic enkephalinergic systems in the rat brain. $J$ Neurosci 3: 844-855, 1983.

28. Khachaturian, H., M. E. Lewis, M. K.-H. Schafer and S. J. Watson. Anatomy of the CNS opioid systems. Trends Neurosci, in press.

29. Khachaturian, H., M. E. Lewis, K. Tsou and S. J. Watson. Beta-endorphin, alpha-MSH, ACTH and related peptides. In: Handbook of Chemical Neuroanatomy, Neuropeptides in the $C N S$, edited by $T$. Holfelt and $A$. Bjortlund. Amsterdam: Elsevier Biomedical Publishers, in press.

30. Khachaturian, H., M. E. Lewis and S. J. Watson. Colocalization of proenkephalin peptides in rat brain neurons. Brain Res 279: 369-373, 1983.

31. Khachaturian, H., M. E. Lewis and S. J. Watson. Enkephalin systems in diencephalon and brain stem of the rat. J Comp Neurol 219: 310-320, 1983.

32. Khachaturian, H., M. E. Lewis and S. J. Watson. Immunocytochemical studies with antisera against leucineenkephalin and an enkephalin-precursor fragment (BAM-22P) in the rat brain. Life Sci 31: 1879-1882, 1982.

33. Khachaturian, H., S. J. Watson, M. E. Lewis, D. Coy, A. Goldstein and H. Akil. Dynorphin immunocytochemistry in the rat central nervous system. Peptides 3: 941-954, 1982.

34. Kosterlitz, H. W., S. J. Paterson and L. E. Robson. Characterization of the Kappa-subtype of the opiate receptor in the guinea-pig brain. Br J Pharmacol 73: 939-949, 1981.

35. Kuhar, M. D. and J. R. Unnerstall. In vitro labeling receptor autoradiography: Loss of label during ethanol dehydration and preparative procedures. Brain Res 24: 178-181, 1982.

36. Lewis, J. W., H. Khachaturian, M. E. Lewis and H. Akil. Opioid peptides: Endogenous analgesics? In: Proceedings of the IX International Congress of Pharmacology, edited by J. F. Mitchell, W. Paton and P. Turner. London: Macmillan Press, Ltd., in press.

37. Lewis, M. E., H. Khachaturian, M. K.-H. Schafer and S. J. Watson. Anatomical approaches to the study of neuropeptides and related mRNA in CNS. In: Neuropeptides in Neurological Disease, ARNMD vol 64, edited by J. B. Martin et al. New York: Raven Press, in press.

38. Lewis, M. E., H. Khachaturian and S. J. Watson. Visualization of opiate receptors and opioid peptides in sequential brain sections. Life Sci 31: 1247-1250, 1982.

39. Lewis, M. E., H. Khachaturian and S. J. Watson. Comparative distribution of opiate receptors and three opioid peptide neuronal systems in rhesus monkey nervous system. Life Sci 33: Suppl 1, 239-242, 1983.

40. Lewis, M. E., H. Khachaturian and S. J. Watson. Combined autoradiographic-immunocytochemical analysis of opiate receptors and opioid peptide neuronal systems in brain. Peptides, in press.

41. Lewis, M. E., M. Mishkin, E. Bragin, R. M. Brown, C. B. Pert and A. Pert. Opiate receptor gradients in monkey cerebral cortex: correspondence with sensory processing hierarchies. Science 211: 1166-1169, 1981.

42. Lewis, M. E., A. Pert, C. B. Pert and M. Herkenham. Opiate receptor localization in rat cerebral cortex. J Comp Neurol 216: 339-353, 1983.

43. Loew, G. H., L. Toll and C. Keys. Computer-assisted analysis

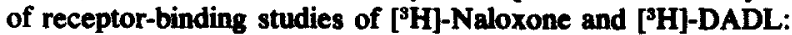
A reinterpretation of the $\mathrm{Na}+$ effect. Life Sci 33: Suppl 1, 163$166,1983$.

44. Lord, J. A. H., A. A. Waterfield, J. Hughes and H. W. Kosterlitz. Endogenous opioid peptides: multiple agonists and receptors. Nature 267: 495-499, 1977.

45. Mains, R. E., B. A. Eipper and N. Ling. Common precursor to corticotropins and endorphins. Proc Natl Acad Sci USA 74: 3014-3018, 1977.

46. Maurer, R., R. Cortes, A. Probst and J. M. Palacios. Multiple opiate receptor in human brain: an autoradiographic investigation. Life Sci 33: Suppl 1, 231-234, 1983. 
47. Mayer, D. J. and J. C. Liebeskind. Pain reduction by focal electrical stimulation of the brain: an anatomical and behavioral analysis. Brain Res 68: 73-93, 1974.

48. McGinty, J. F., D. van der Kooy and F. E. Bloom. The distribution and morphology of opioid peptide immunoreactive neurons in the cerebral cortex of rats. $J$ Neurosci 4: 1104-1117, 1984.

49. McGinty, J. F., D. van der Kooy, L. Y. Koda and F. E. Bloom. Enkephalin immunoreactive cells in frontal, olfactory and limbic cortex. Anat Rec 202: 125A, 1982.

50. Miller, R. How do opiates act? Trends Neurosci 7: 184-185, 1984.

51. Nakanishi, S., A. Inoue, T. Kita, M. Nakamura, A. C. Y. Chang, S. N. Cohen and S. Numa. Nucleotide sequence of cloned cDNA for bovine corticotropin-beta-lipotropin precursor. Nature 278: 423-427, 1979.

52. Noda, M., Y. Furutani, H. Takahashi, M. Toyosato, T. Hirose, S. Inayama, S. Nakanishi and S. Numa. Cloning and sequence analysis of cDNA for bovine adrenal preproenkephalin. Nature 295: 202-206, 1982.

53. Noda, M., Y. Teranishi, H. Takahashi, M. Toyosato, M. Notake, S. Nakanishi and S. Numa. Isolation and structural organization of the human preproenkephalin gene. Nature 297: 431-434, 1982.

54. Pert, A. and T. Yaksh. Sites of morphine-induced analgesia in the primate brain: relation to pain pathways. Brain Res 80: 135-140, 1974.

55. Przewlocki, R., L. Stala, M. Greczek, G. T. Shearman, B. Przewlocka and A. Herz. Analgesic effects of mu-, delta- and kappa-opiate agonists and, in particular, dynorphin at the spinal level. Life Sci 33: Suppl 1, 649-652, 1983.

56. Quirion, R., W. Bowen, M. Herkenham and C. B. Pert. Visualization and solubilization of rat brain opiate receptors with a "kappa" ligand selectivity pattern. Cell Mol Neurobiol 2: 333$345,1982$.

57. Quirion, R. and A. S. Weiss. Peptide E and other proenkephalin-A derived peptides are potent kappa opiate receptor agonists. Peptides 4: 445-449, 1983.

58. Quirion, R., A. S. Weiss and C. B. Pert. Comparative pharmacological properties and autoradiographic distribution of $\left[{ }^{3} \mathrm{H}\right]$ ethylketocyclazocine binding sites in rat and guinea pig brain. Life Sci 33: Suppl 1, 183-186, 1983.

59. Quirion, R., J. M. Zajac, J. L. Morgat and B. P. Roques. Autoradiographic distribution of $\mathrm{mu}$ and delta opiate receptors in rat brain using highly selective ligands. Life Sci 33: Suppl 1, 227-230, 1983.

60. Richardson, D. E. and H. Akil. Pain reduction by electrical brain stimulation in man-Part $I$ : Acute administration in periaqueductal and periventricular sites. I Neurosurg 47: 178 . 183, 1977.

61. Richardson, D. E. and H. Akil. Pain reduction by electrical brain stimulation in man-Part 2: Chronic self-administration in the periventricular gray matter. J Neurosurg 47: 184-194, 1977.

62. Roberts, J. L. and E. Herbert. Characterization of a common precursor to corticotropin and beta-lipotropin: Cell-free synthesis of the precursor and identification of corticotropin peptides in the molecule. Proc Natl Acad Sci USA 74: 4826-4830, 1977.

63. Roberts, J. L. and E. Herbert. Characterization of a common precursor to corticotropin and beta-lipotropin: Identification of beta-lipotropin peptides and their arrangement in a cell-free system. Proc Natl Acad Sci USA 74: 5300-5304, 1977.

64. Robson, L. E., S. J. Paterson and H. W. Kosterlitz. Multiple opioid receptors. In: Handbook of Psychopharmacology, edited by L. L. Iversen, S. D. Iversen and S. H. Snyder. New York: Plenum Press, 1983, pp. 13-80.
65. Romer, D., H. Buscher, R. C. Hill, R. Maurer, T. J. Petcher, H. B. A. Welle, H. C. C. K. Bakel and A. M. Akkerman. Bremazocine: a potent, long-acting opiate kappa-agonist. Life $\mathrm{Sc}_{\mathrm{ci}}$ 27: 971-978, 1980.

66. Sar, M., W. E. Stumpf, R. J. Miller, K.-J. Chang and P. Cuatrecasas. Immunohistochemical localization of enkephalin in rat brain and spinal cord. J Comp Neurol 182: 17-38, 1978.

67. Satoh, M., A. Kubota, T. Iwama, T. Wada, M. Yasui, K. Fujibayashi and $\mathbf{H}$. Takagi. Comparison of analgesic potencies of mu, delta and kappa agonists locally applied to various CNS regions relevant to analgesia in rats. Life Sci 33: Suppl 1,689. $692,1983$.

68. Schmauss, C., T. L. Yaksh, Y. Shimohigashi, G. Harty, T. Jensen and D. Rodbard. Differential association of spinal mu, delta a, and kappa opioid receptors with cutaneous thermal and visceral chemical nociceptive stimuli in the rat. Life $S_{c} i$ 33; Suppl 1, 653-656, 1983.

69. Simantov, R., M. J. Kuhar, G. R. Uhl and S. H. Snyder. Opioid peptide enkephalin: Immunohistochemical mapping in rat central nervous system. Proc Natl Acad Sci USA 74: 2167-2171. 1977.

70. Stengaard-Pedersen, K. Comparative mapping of opioid receptors and enkephalin immunoreactive nerve terminals in the rat hippocampus. A radiohistochemical and immunocytochemical study. Histochemistry 79: 311-333, 1983.

71. Vincent, S., T. Hokfelt, I. Christensson and L. Terenius. Immunohistochemical evidence for a dynorphin immunoreactive striato-nigral pathway. Eur J Pharmacol 85: 251-252, 1982.

72. Wamsley, J. K., W. S. Young, III and M. J. Kuhar. Immunohistochemical localization of enkephalin in rat forebrain. Brain Res 190: 153-174, 1980.

73. Wamsley, J. K., M. A. Zarbin, W. S. Young, III and M. J. Kuhar. Distribution of opiate receptors in the monkey brain: An autoradiographic study. Neuroscience 7: 595-613, 1982.

74. Watson, S. J., H. Akil, W. Fischli, A. Goldstein, E. Zimmerman, G. Nilaver and T. B. van Wimersma Greidanus. Dynorphin and vasopressin: Common localization in magnocellular neurons. Science 216: 85-87, 1982.

75. Watson, S. J., H. Akil, H. Khachaturian, E. Young and M. E. Lewis. Opioid systems: Anatomical, physiological and clinical perspectives. In: Opioids: Past, Pre'sent and Future. edited by J. Hughes, H. O. J. Collier, M. J. Rance and M. B. Tyers. London: Taylor and Francis Limited, 1984.

76. Watson, S. J., H. Akil, S. O. Sullivan and J. D. Barchas. Immunocytochemical localization of methionine-enkephalin: Preliminary observations. Life Sci 25: 733-738, 1977.

77. Watson, S. J., H. Khachaturian, H. Akil, D. Coy and A. Goldstein. Comparison of the distribution of dynorphin systems and enkephalin systems in brain. Science 218: 1134-1136, 1982.

78. Werz, M. A., M. E. Lewis, D. S. Grega, S. J. Watson and R. L. Macdonald. Heterogeneity of opioid receptors on dorsal root ganglion neurons in culture: A combined autoradiographic and electrophysiological study. Soc Neurosci Abstr 10: 585, 1984.

79. Wise, S. P. and M. Herkenham. Opiate receptor distribution in the cerebral cortex of the rhesus monkey. Science 218: 387-389, 1982.

80. Woods, J. H., A. M. Young and S. Herling. Classification of narcotics on the basis of their reinforcing, discriminative, and antagonist effects in rhesus monkeys. Fed Proc 41: 221-227. 1982.

81. Young, E., J. M. Walker, R. Houghten and H. Akil. [ ${ }^{3} \mathrm{H}$ ]dynorphin A binds selectively to guinea pig brain. Eur J Pharmacol 91: 327-328, 1983.

82. Zajac, J.-M., G. Gacel, F. Petit, P. Dodey, P. Rossignol and B. P. Roques. Deltakephalin, Tyr-D-Thr-Gly-Phe-Leu-Thr: A new highly potent and fully specific agonist for opiate deltareceptors. Biochem Biophys Res Commun 111: 390-397. 1983. 